\title{
Playing the indigenous card? The Shetland and Orkney Udal Law group and indigenous rights
}

\author{
Michael Jones
}

Published online: 27 August 2010

(C) The Author(s) 2010. This article is published with open access at Springerlink.com

\begin{abstract}
The term 'indigenous peoples' generally refers to the original inhabitants of areas of the world colonized by Europeans. Relatively few ethnic minorities in Europe have been recognized as indigenous. A consequence of globalization is that knowledge of rights gained by indigenous groups in different parts of the world has led to explicit or implicit claims for indigenous status by organized groups within some European ethnic or regional minorities. An example from the Northern Isles of Scotland is the Shetland and Orkney Udal Law group (SOUL), which includes on its website links to legal decisions supporting indigenous rights in Canada and Australia. SOUL argues for greater local autonomy regarding the use of resources. The islands were inhabited by Norse settlers from Scandinavia from the 9th century AD and came under Scottish rule in the 1460s. Certain elements of Norse law related to land tenure, in particular foreshore rights, have survived to the present as a form of customary law referred to as udal law. Udal law has been the subject of court cases in the nineteenth and
\end{abstract}

Revised version of a paper presented at the Inaugural Meeting of the International Geographical Union (IGU) Commission on Indigenous Peoples' Knowledges and Rights, October 29November 3, 2007, Taipei, Taiwan.

M. Jones $(\square)$

Department of Geography, Norwegian University of Science and Technology (NTNU), 7491 Trondheim, Norway

e-mail: Michael.Jones@svt.ntnu.no twentieth centuries. It has been presented as symbolizing Orkney and Shetland identity, and brought into public debates on matters of concern to Orcadians and Shetlanders. Udal law is invoked to support a claim for local control over the surrounding sea and seabed, important for fishing, salmon-farming and oil exploitation. These issues are examined in relation to definitions of indigenous peoples applied by the United Nations, International Labour Organisation, and World Bank.

Keywords Identity · Indigenous peoples (definitions) $\cdot$ Land tenure $\cdot$ Orkney $\cdot$ Shetland · Udal law

\section{Introduction}

The term 'indigenous peoples' is primarily thought of as referring to the original or native inhabitants of areas that have been colonized by other groups of people-especially in Africa, Asia, America and Australasia, in areas that were colonized by Europeans. Within Europe, however, only a limited number of ethnic minorities have been considered to be indigenous peoples-mainly in the northern and eastern margins of the continent. Apart from various FinnoUgric and other minority peoples in Russia, only the Saami in Scandinavia and the Basques in Spain and France have been generally recognized as indigenous 
peoples. ${ }^{1}$ However, one consequence of globalization is that knowledge of the struggles undergone by indigenous groups in different parts of the world-and rights gained by them-has led to consideration of explicit or implicit claims for indigenous status by organized groups within some European ethnic or regional minorities.

An example from the Northern Isles of Scotland is the Shetland and Orkney Udal Law group (SOUL), which includes on its website links to legal decisions in favour of indigenous rights in Canada and Australia (S.O.U.L. n.d.). SOUL argues in favour of greater autonomy for Shetland and for Shetland's resources to be used for the maximum benefit of Shetland people. The notion of udal law is invoked to support a claim for local control over the surrounding sea and seabed, important for the fishing industry, salmon-farming and oil exploitation (SOUL 2004, 10-16). The historical argument for this claim is that Orkney and Shetland were inhabited by Norse settlers from Scandinavia from the ninth century AD. The islands came under Scottish rule in the late 1460s, and following increasing settlement from the Scottish mainland Norse law was superseded by Scots law in the seventeenth century. However, certain elements of Norse law, principally related to land tenure and in particular foreshore rights, have survived until the present time as a form of customary law still referred to as udal law (pertaining to allodial rights) (Jones 1996a; 1996b [2001]; 2005, 101-105).

Using SOUL as a case study, this paper will address the question: How does globalization of the indigenous discourse influence debates on minority claims by regional or ethnic minority groups that have not earlier described themselves or been described by others as indigenous?

The paper will first discuss varying definitions of indigenous peoples from 1957 to the present by the International Labour Organization (ILO), United Nations (UN) and World Bank (WB). This will be followed by a presentation of udal law, a contested survival of the old Norse legal system that applied in Orkney and Shetland when the islands passed from Danish-Norwegian to Scottish rule in 1468-1469. This section will briefly examine the historical antecedents of the transfer of sovereignty, survivals

\footnotetext{
${ }^{1}$ See for example the list of indigenous peoples of Europe in Wikipedia (2005).
}

of udal tenure, legal decisions relating to udal law, the role of udal law in feelings of local identity, and its evocation in a number of public debates in recent times. Then the objectives and activities of SOUL will be presented, especially in the light of the organization's interest in indigenous rights. Finally, the paper will examine these issues in relation to the definitions of indigenous peoples applied by the international organizations.

\section{Definitions of indigenous peoples}

The category of 'indigenous populations' was adopted for the first time in international law by the International Labour Organization in ILO Convention no. 107 of 1957 concerning the protection and integration of indigenous and tribal populations in independent countries. According to Article 1, the convention applied to

(a) members of tribal or semi-tribal populations in independent countries whose social and economic conditions are at a less advanced stage than the stage reached by the other sections of the national community, and whose status is regulated wholly or partially by their own customs or traditions or by special laws or regulations;

(b) members of tribal or semi-tribal populations in independent countries which are regarded as indigenous on account of their descent from the populations which inhabited the country, or a geographical region to which the country belongs, at the time of conquest or colonisation and which, irrespective of their legal status, live more in conformity with the social, economic and cultural institutions of that time than with the institutions of the nation to which they belong (International Labour Organization 2006 [1957]).

This early convention was characterized by Lâm (2008 [2004], 427) as 'remarkably assilimationist'.

In 1972, the United Nations Commission on Human Rights initiated a study of the problem of discrimination against indigenous populations, which was undertaken by José R. Martínez Cobo, Special Rapporteur of the Sub-Commission on Prevention of Discrimination and Protection of Minorities. A preliminary definition of 'indigenous populations' was as follows: 
Indigenous populations are composed of the existing descendents of the peoples who inhabited the present territory of a country wholly or partially at the time when persons of a different culture or ethnic origin arrived there from other parts of the word, overcame them, by conquest, settlement or other means, reduced them to a nondominant or colonial condition; who today live more in conformity with their particular social, economic and cultural customs and traditions than with the institutions of the country of which they now form part, under a state structure which incorporates mainly national, social and cultural characteristics of other segments of the population which are predominant.

In 1982, the Sub-Commission set up a Working Group on Indigenous Populations (WGIP), which in 1983 widened the definition to include other isolated or marginal societies in addition to the descendants of pre-colonial populations, as follows:

(a) they are the descendants of groups, which were in the territory at the time when other groups of different cultures or ethnic origin arrived there;

(b) precisely because of their isolation from other segments of the country's population they have almost preserved intact the customs and traditions of their ancestors which are similar to those characterized as indigenous;

(c) they are, even if only formally, placed under a state structure which incorporates national, social and cultural characteristics alien to their own. ${ }^{2}$

Cobo concluded in 1986 his voluminous Study on the Problem of Discrimination against Indigenous Populations (United Nations 1987) and provided a comprehensive working definition of the concept of indigenous communities, as follows:

Indigenous communities, peoples and nations are those which, having a historical continuity with pre-invasion and pre-colonial societies that developed on their territories, consider themselves distinct from other sectors of the societies now prevailing on those territories, or parts of them. They form at present non-dominant sectors of society and are determined to preserve,

$\overline{2}$ The texts of the 1972 and 1983 definitions of indigenous peoples can be found in Wikipedia (2007). develop and transmit to future generations their ancestral territories, and their ethnic identity, as the basis of their continued existence as peoples, in accordance with their own cultural patterns, social institutions and legal system.

This historical continuity may consist of the continuation, for an extended period reaching into the present of one or more of the following factors:

(a) Occupation of ancestral lands, or at least of part of them;

(b) Common ancestry with the original occupants of these lands;

(c) Culture in general, or in specific manifestations (such as religion, living under a tribal system, membership of an indigenous community, dress, means of livelihood, lifestyle, etc.);

(d) Language (whether used as the only language, as mother-tongue, as the habitual means of communication at home or in the family, or as the main, preferred, habitual, general or normal language);

(e) Residence on certain parts of the country, or in certain regions of the world;

(f) Other relevant factors.

On an individual basis, an indigenous person is one who belongs to these indigenous populations through self-identification as indigenous (group consciousness) and is recognized and accepted by these populations as one of its members (acceptance by the group).

This preserves for these communities the sovereign right and power to decide who belongs to them, without external interference. ${ }^{3}$

In 1989, ILO Convention no. 107 was superseded by ILO Convention 169 on indigenous and tribal peoples, which according to Article 1 applies to the following groups:

(a) Tribal peoples in independent countries whose social, cultural and economic conditions distinguish them from other sections of the national community, and whose status is regulated wholly or partially by their own customs or traditions or by special laws or regulations;

\footnotetext{
${ }^{3}$ Cobo's working definition of 1986 is reproduced in United Nations 2004, 2.
} 
(b) People in independent countries who are regarded as indigenous on account of their descent from the populations which inhabited the country, or a geographical region to which the country belongs, at the time of conquest or colonization or the establishment of present state boundaries and who, irrespective of their legal status, retain some or all of their own social, economic, cultural and political institutions (International Labour Organization 2006 [1969]).

Article 1 of the convention further states:

Self-identification as indigenous or tribal shall be regarded as a fundamental criterion for determining the groups to which the provisions of this Convention apply.

The World Bank in its operational directive of 1991 defined indigenous peoples as follows:

Indigenous peoples can be identified in particular geographical areas by the presence in varying degrees of the following characteristics:

(a) close attachment to ancestral territories and to the natural resources in these areas;

(b) self-identification and identification by others as members of a distinct cultural group;

(c) an indigenous language, often different from the national language;

(d) presence of customary social and political institutions; and

(e) primarily subsistence-oriented production (World Bank 1991).

In 2005 the World Bank replaced this operational directive with an operational policy containing a modified definition of indigenous peoples, in which the reference to subsistence-oriented production was removed, as follows:

...the term "Indigenous Peoples" is used in a generic sense to refer to a distinct, vulnerable, social and cultural group possessing the following characteristics in varying degrees:

(a) self-identification as members of a distinct indigenous cultural group and recognition of this identity by others;

(b) collective attachment to geographically distinct habitats or ancestral territories in the project area and to the natural resources in these habitats and territories;

(c) customary cultural, economic, social, or political institutions that are separate from those of the dominant society and culture; and

(d) an indigenous language, often different from the official language of the country or region (World Bank 2005).

In the meantime, after considerable debate and discussion, the WGIP completed in 1994 a United Nations Draft Declaration on the Rights of Indigenous Peoples, which supported the right of self-determination (Lâm 2008 [2004], 427-429). ${ }^{4}$ This did not define indigenous peoples. However, a WGIP working paper by the Chairperson-Rapporteur, Erica-Irene A. Daes, in 1996 summarized factors that international organizations and legal experts have considered relevant to understanding the concept of 'indigenous', as follows:

(a) Priority in time, with respect to the occupation and use of a specific territory;

(b) The voluntary perpetuation of cultural distinctiveness, which may include the aspects of language, social organization, religion and spiritual values, modes of production, laws and institutions;

(c) Self-identification, as well as recognition by other groups, or by States authorities, as a distinct collectivity; and

(d) An experience of subjugation, marginalization, dispossession, exclusion or discrimination, whether or not these conditions persist (United Nations 1996).

The United Nations Declaration on the Rights of Indigenous Peoples was finally adopted by the UN General Assembly on 13 September 2007 and again does not give a definition of indigenous peoples. According to Article 33 of the Declaration:

Indigenous peoples have the right to determine their own identity or membership in accordance with their customs and traditions. (United Nations 2007)

From the above definitions can be condensed the following eleven characteristics of indigenous peoples:

\footnotetext{
${ }^{4}$ See Falk et al. $(2008,158-170)$ for the full text of the 1994 Draft Declaration.
} 
- Colonized people, or descendents of groups in a territory when other groups of different cultures or ethnic origins arrived there (ILO $57 \& 89$, UN $72,83,86 \& 96)$

- Culturally distinctive group belonging to a state with alien characteristics (ILO $57 \& 89$, UN 72, 83,86 \& 96)

- Regulated by own customs or special laws and regulations (ILO $57 \&$ 89, UN 86 \& 96)

- Close attachment to ancestral territories and natural resources there (UN 86, WB 91 \& 05)

- Self-identification and identification by others (UN $86 \& 96$, WB $91 \& 05$ )

- Indigenous language (UN 86 \& 96, WB 91 \& 05)

- Own customary social and political institutions (ILO $57 \&$ 89, UN 72, $83 \&$ 86, WB $91 \& 05$ )

- Tribal peoples (ILO $57 \& 89$ )

- Subsistence-oriented (WB 91)

- Experience of subjugation, marginalization, dispossession, exclusion or discrimination (UN 96)

- Self-determination (UN 86, 96 \& 07, ILO 89)

\section{Udal Law}

Historical antecedents

The settlement of Orkney and Shetland by Vikings from Norway began around $800 \mathrm{AD}$. The pre-existing population of Picts were either brutally eradicated or assimilated though marriage (Bäcklund 2001; Smith 2001). At its greatest extent in 1262, the medieval Norwegian realm included in addition to mainland Norway not only Orkney, Shetland and the other North Atlantic islands (the Faroes, Iceland and Greenland) but also the Hebrides and the Isle of Man. In 1274 the Law Code of King Magnus of Norway (Magnus Code) was adopted in the Northern Isles. From 1330, the Earls of Orkney were Scottish, although under Norwegian suzerainty. This was followed in the succeeding centuries by the growing acquisition of estates in Orkney and Shetland by Scots and the immigration of Scottish settlers. Scandinavian rule ended in Orkney in 1468 and in Shetland in 1469, when the king of Denmark and Norway, Christian I, pawned the islands to the Scottish king James III in lieu of a dowry for Christian's daughter Margrethe (Margaret). The treaties of 1468 and 1469 provided implicitly for the continuation in Orkney and Shetland of existing laws, and the Scottish Parliament in 1547 specifically recognized that the islands had their own laws. Nonetheless the gradual imposition of Scots law and legal practice occurred. In 1611, an Act of the Scottish Privy Council proscribed the 'foreign laws' of Orkney and Shetland. Such aspects of the old laws that survived were henceforth dependent on memory and oral tradition, and came to be regarded as customs within a corpus of Scots law (Crawford 1969; Smith 1973, 153-157; 1989, 221; Fenton 1978, 1-3; Ryder, 1989, 195-198; Jones 1996b [2001], 4; Thomson 2001 [1987], 267-269).

Survivals of udal tenure in 20th century

By the twentieth century, the only remaining survivals of the Magnus Code were certain local peculiarities regarding land tenure. The term 'udal' comes from the Norse word oðal—in modern Norwegian odel — which means right of full possession. Until the passing of the Abolition of Feudal Tenure etc. (Scotland) Act by the new Scottish Parliament in 2000, most land in Scotland was for legal purposes subject to feudal tenure, whereas udal land was (and remains) allodial, i.e. the title never emanated from the Crown and there was no feudal superior (Drever 1933, 323, 328-329; Dobie 1936, 451-453; Smith 1978, 197, 199; Ryder 1989, 193, 201-202; Jones 1996b [2001], 5; Office of Public Sector Information 2000).

One feature of udal tenure is that landowners have rights of ownership to the foreshore (between high and low water) adjoining their land, unlike in mainland Scotland where the foreshore could only be held from the Crown as superior. Similarly, landowners have rights to salmon-fishing adjoining their land, whereas in mainland Scotland salmon-fishing belongs to the Crown. Another feature was that landowners in Orkney and Shetland were subject to the payment of scat, a land tax of Norse origin; although this has largely been redeemed, there were at the end of the twentieth century still a few landowners paying scat. In Shetland the hill grazings are termed scattalds, a territorial unit of ownership of Norse origin; scattalds are generally in the joint ownership of several owners (unlike in mainland Scotland where the hill grazings belong usually to large estates), while grazing rights are held by crofters. Finally there is evidence that partible inheritance and rights of kin to land, which 
are institutions of Norse origin and still practised in Norway today, continued to be practised in some families in Orkney and Shetland until the 20th century, as opposed to the Scots principle until 1964 of primogeniture (Jones 1996a, 187-193; 1996b [2001], 8-9; 2005, 101-102).

Legal decisions concerning udal law

Between 1890 and 1990, a number of legal cases concerning udal law were judged by the courts, five of them being decided by the Court of Session, Scotland's supreme court (Jones 1996a, 186-193; 1996b [2001], 7-8).

The Hoswick whale case (Bruce v. Smith) in 1890 concerned the claim of a landowner to one-third of the proceeds of pilot whales ('caaing whales') driven up onto his shore. The claim appeared to derive from the Magnus Code. The landowner's claim was contested by the captors. Under Scots law, landowners had no rights to whales. The Court of Session found the landowner's claim to be an unreasonable custom, lacking the consent of the local community.

In judging a disputed inheritance in 1893, the local Sheriff Court upheld the law of udal succession, ordering the disputed land to be divided among all the heirs (two sons and two daughters) rather than following the rule in Scots law of primogeniture in cases of intestacy (Dickinson 1954, 159-160).

In the Sinclair's Beach case of 1903 (Smith v. Lerwick Harbour Trustees), a local merchant claimed title to foreshore adjoining his land on the grounds that the latter was udal land. The Lerwick Harbour Trustees claimed the foreshore was Crown property. The Court of Session found that the foreshore adjoining udal land was allodial, and that the Crown grant to Lerwick Harbour Trustees was not valid.

In the Balfour case of 1907 (Lord Advocate v. Balfour), a riparian owner claimed salmon-fishing rights offshore. Under Scots law, salmon-fishing belonged to the Crown as a feudal right. The Court of Session found that salmon-fishings did not constitute a separate feudal estate in Orkney and Shetland, but were a part and pertinent of landownership. The right of salmon-fishing had never been claimed by the Crown of Norway, and hence never conferred on the Crown of Scotland.

In the St. Ninian's Isle Treasure Case of 1963 (Lord Advocate v. Aberdeen University and Budge), the finders of a cache of treasure claimed that, as it had been found on udal land, it should be divided according to Magnus Law: one-third to the finders, one-third to the landowner, and one-third to the Crown. The Crown claimed the treasure under Scots law. The Court of Session accepted that the land was allodial, but found nonetheless that the treasure belonged to the Crown, not as feudal superior but as part of its sovereign rights.

Finally, in the seabed case of 1990 (Shetland Salmon Farmers Association v. Crown Estate Commissioners), the Shetland Salmon Farmers' Association contested the right of the Crown Estate Commissioners to charge rent for the use of the seabed by salmon farmers. The salmon farmers claimed that under udal law the Crown could not be the owner of the seabed off Shetland and Orkney as the Norwegian Crown had never claimed the seabed. The Crown Estate Commissioners claimed seabed ownership off the shores of Shetland and Orkney as elsewhere in Britain. The Court of Session found that the seabed belonged to the Crown as part of its sovereign rights, not its rights as feudal superior.

Rights derived from udal law were thus upheld by the Sheriff Court in one case and by the Court of Session in two of these cases, and rejected by the Court of Session in three of the cases.

Udal law as a symbol of Orkney and Shetland identity

In the second half of the ninteenth century, udal law became a focus of attention due to a Norse cultural revival among middle-class intellectuals. A source of grievance among landowners was double taxation, since they not only paid the land taxes normal in the rest of Scotland but also paid scat. In 1886, the Reform League for Orkney and Shetland, soon renamed the Udal League, was founded to campaign for Home Rule. The League advocated land reform and the conversion of farm tenants to owner-occupiers. Renamed the Udal Rights Association in 1886, it organized a petition against double taxation, demanding an end to payment of scat. The Udal Rights Association faded away after 1892, when the Viking Club was founded in London and devoted its attention to the pursuit of the land-tenure history of the Northern Isles (Thomson 1985; Townsend 1992; Jones 1996a, 193; 1996b [2001], 5-6). 
Norse motifs were adopted on town and county coats of arms. Earliest was the Burgh of Lerwick in 1882, followed by Orkney County Council in 1931, Zetland County Council in 1956, and the new Orkney Islands Council and Shetland Islands Council in 1975. In the case of Shetland a motto from the medieval Scandinavian law codes was also adopted, and can still be seen on a welcoming-sign at Lerwick Harbour. Lerwick was the venue of the First Viking Congress, convened in 1950, which included udal law on it academic programme of lectures (Jones 1996b [2001], 6-7).

\section{Udal law in public debates}

During the second half of the twentieth century, udal law became a symbol of Orkney and Shetland identity in popular travel literature, a trend that has continued into the 21 st century. It has been brought at regular intervals into public debates on matters of concern to Orcadians and Shetlanders, such as local government reform in the 1960s. In the 1970s it was used to emphasize the distinctiveness of the islands in discussions of constitutional reform for Scotland. The Shetland Movement and the Orkney Movement, agitating for local autonomy, referred to udal law in the 1970s and 1980s. In the early 1980s, it was invoked by opponents of proposed uranium mining, and in the mid-1980s by opponents of the designation of Sites of Special Scientific Interest, held to be infringing udal rights. Following the failure of the case against the imposition of a seabed rental on salmon farmers in 1990, udal law became an issue again in 2001 and 2002 in opposition to possible changes in the status of the foreshore under the Scottish land tenure reform programme (Jones 1996b [2001], 7; 2005, 102-103).

\section{SOUL}

During the lead-up to the Scottish Parliamentary elections in 2003, various groups made demands for local control of the sea and seabed in the contexts of both fishing and offshore oil, as well as local autonomy under which udal rights and laws would be restored. The Shetland Conservative Association issued a manifesto summarizing what was termed 'Shetland's Udal Case' and demanded the 'restoration of Shetland's Udal Rights and Norse laws'. At the same time 'a loose association of Shetland individuals and business people' distributed with a local newspaper, The Shetland Times, an anonymous brochure proclaiming that 'Udal law is our law', which elicited 386 responses from people who signed an appeal supporting 'Shetland's Udal/Norse Law'. At the same time the Shetland \& Orkney Udal Law Group (SOUL) set up a 'Udal Law website', on which it was argued that udal law was necessary for the 'economic and cultural survival of the Northern Isles'. The claims of these groups were refuted by the Shetland archivist on the grounds that they were historically inaccurate ${ }^{5}$ (Jones 2005, 103).

Undaunted, SOUL issued in 2004 The SOUL Report, presenting its own historical interpretation of udal law and arguing for a measure of autonomy for Shetland and Orkney. One of the arguments drew a parallel with indigenous struggles in other parts of the world:

In a strange way Shetland and Orkney find themselves in a similar situation to the native peoples of Australia, New Zealand and Canada. There, just as here, the feudal system was imposed by a foreign power onto an already existing (allodial) structure. ... SOUL is encouraged by the fact that successful court case have been brought by native communities (SOUL 2004, 10).

Reference was made to the Mabo case of 1992 in Australia (Mabo and others v. Queensland), in which the High Court of Australia recognized that "native title to their traditional lands, held in accordance with the laws and customs of the indigenous inhabitants had not been extinguished by annexation'. It was further argued that udal law could be considered the indigenous legal system of Orkney and Shetland:

It is a recognised feature of law that the original foundation, or indigenous legal system in a country is (unless eradicated) of enormous legal significance. ...A similar situation might be said to apply in Orkney and Shetland. Although the indigenous peoples such as the Celts and the Picts no doubt had customs by which they regulated their lives, it would be going to far to

\footnotetext{
5 See http://www.udallaw.com (S.O.U.L. n.d.); Shetland Times 23.3.2003; 11. 4. 2003; 16.5.2003; 30.5.2003.
} 
describe those customs as a legal system. Accordingly, the very first legal system in Orkney and Shetland was the Udal law that the Vikings brought with them. ...Furthermore, Udal law was not only introduced into the Islands as their founding legal system but was also a legal system that was applied on an uninterrupted basis for many years (from about 900 AD to date) (SOUL 2004, 18).

The Udal Law website also includes links to legal decisions in favour of indigenous land titles in Australia (the Mabo case of 1992) and Canada (the Delgamuukw case of 1997).

According to information from SOUL in October 2007, the organization has just over 1,000 members, but only a very few are active. SOUL is currently concentrating on doing research on legal and constitutional issues relating to Shetland. ${ }^{6}$ The total population of Shetland according to the census of 2001 was 21,988 and of Orkney 19,245 inhabitants (General Registry Office of Scotland 2001).

\section{Discussion}

There is no evidence that SOUL has widespread support in Orkney and Shetland. However, arguments that the inhabitants of the islands might be comparable to indigenous peoples in other parts of the world raise interesting issues of principle. In relation to the eleven characteristics of indigenous peoples presented above, the following conclusions can be drawn:

A colonized people and prior occupation?

The questions of colonization and prior occupation are problematic. The Norse Vikings came as colonizers and, with their settlement of the islands, traces of the previous population rapidly disappeared. Later settlement on the islands by Scots appears to have been a largely peaceful process, with the Scots obtaining estates through intermarriage or purchase, despite periods of oppression by Scottish lords.

\footnotetext{
${ }^{6}$ Information by e-mail from members of SOUL, October 2007.
}

A culturally distinctive group in a state with alien characteristics?

Scottish political and cultural influence in the islands made itself felt from at least the fourteenth century, particularly in Orkney, with the establishment of a Scottish dynasty of Earls. With the transfer of sovereignty to Scotland in the mid-fifteenth century, 500 years of Norse rule and cultural influence were succeeded by five hundred years of dominating Scots influence. Historically, a diminishing number of small estate owners tracing their ancestry back to their Norse forebears may well have resented growing Scots influence and in some cases hung onto their own customs regarding landownership until recent times. Udal law has frequently been drawn attention to as a distinctive feature of Orkney and Shetland in public debates where local interests have been seen to be threatened. Nonetheless, although Orkney and Shetland have a peripheral location in Scotland, the islands exhibit today a large degree of assimilation and integration with the rest of the country.

Own customs and laws?

The ordinary statute and municipal law of Scotland operates in Orkney and Shetland, except where modified by local specialities or udal survivals. Most lawyers do not regard survivals of udal tenure as a separate system of law but as customary rights within Scots law. An alternative view held by some lawyers is that udal law can be regarded as a separate system of law but one that has been eroded by the adoption of Scots common law and statutes, the jurisdiction of Scottish courts and the political ascendancy of Scotland (Sellar 1987, 191-194; Smith 1989, 222-225).

Attachment to ancestral territories and natural resources?

People in Orkney and Shetland can be heard to say that the islands are not part of Scotland. Many recognize attachments to both Norway and Scotland as ancestral territories. There is a strong sense of regional identity. Local resources are important, particularly sea fish and grazing land, while offshore oil and salmon-farming have become significant since the 1970s. Farming, fishing, the oil industry and 
salmon-farming are enduring topics of discussion in the local newspapers. There is strong resentment in some quarters against the fishing-policies of the European Union, as well as against the payment of rentals to the Crown Estate for fish farms. Legal challenges to Crown over the ownership of salmonfishing rights and the foreshore were successful in the early years of the twentieth century, but unsuccessful in the case of treasure trove and the seabed in the second half of the century.

Self-identification and identification by others?

It is doubtful whether many Orcadians and Shetlanders would identify themselves as an indigenous group. However, there is considerable self-identification and some identification by others that the islanders form to some degree distinct groups culturally with a mixed Norse and Scots heritage.

Indigenous language?

The old Norn language of Orkney and Shetland, derived from the Norse spoken in the Middle Ages, is no longer spoken, having largely died out by the 18 th century. However, words of Norn origin survive in the local dialect (Jakobsen 1985 [1928]). Although the people of the islands speak their own dialect of Scots, the pronunciation differs from Scots to a certain extent.

Own customary social and political institutions?

The remnants of udal tenure are few and becoming attenuated. Udal law is evoked in public debates but is not widely accepted as a valid, separate system of law but rather seen as a curiosity. However, there is a strong awareness of the islands' Norse heritage. An annual fire festival with Viking imagery, known as 'Up Helly Aa', is a popular event in Shetland each January (Brown 1998). With regard to local political institutions, the Islands Councils established for respectively Orkney and Shetland in 1975 (as well as for the Western Isles of Scotland) had until 1996 a status somewhat different from other local administrative units in Scotland. In response to the discovery of oil in the North Sea in the 1970s, the Zetland County Council Act was passed in 1974 giving Shetland strong local control over harbour regulation and planning related to offshore oil activities. A similar Act was passed for Orkney the same year.

Tribal people?

The term 'tribal' is problematic because it is frequently associated with past attitudes of white colonialists towards so-called primitive or uncivilized peoples. The term has not been invoked in relation to the people of Orkney and Shetland.

Subsistence-oriented?

Fishing, farming and crofting are only to a very limited degree subsistence-oriented; today these livelihoods are primarily commercially oriented. The provision of services related to the offshore oil industry and to the commercial fishing fleet is important particularly in Shetland.

Experience of subjugation, marginalization, dispossession, exclusion or discrimination?

Until the early 1950s, Orkney historians in particular emphasized the Norse period in their works, frequently contrasting it positively with the perceived oppressions of Scottish rule (Jones 1996b [2001], 5; Øien 2005). The misuse of weights and measures inherited from the Norse period and the question of double taxation led in the 18th and 19th centuries to books and pamphlets detailing the 'grievances' of landowners over the 'oppressions' of the earls and other officials charged with administering the islands (e.g. Mackenzie 1836 [1750]; Balfour 1859). More recent historical works have given greater balance to the mixed benefits of both the Norse and Scottish legacy (Thomson 2001 [1987]). Claims by groups such as SOUL that udal law should be restored as the rightful law of Orkney and Shetland have been refuted by local historians.

\section{Self-determination?}

The Orkney and Shetland Movements, established at the end of the 1970s, formed a coalition in the 1987 general election, campaigning for greater local autonomy for the islands. The movements gained a certain success in local elections but not to a degree that self-determination became a majority issue. The 
movements continued their activities in the 1990s, but, although not formally disbanded, have been less active since then. ${ }^{7}$ The Orkney and Shetland Movements were regionalist movements (Bennett 1985) but did not identify themselves as indigenous movements. SOUL, by contrast, has compared itself with indigenous movements elsewhere in the world when arguing for local autonomy.

\section{Conclusion}

On balance, it is doubtful whether claims for indigenous status for Orcadians and Shetlanders could be sustained. Today the significance of udal law is less as law in the strictly legal sense than as a cultural phenomenon that expresses certain feelings of regional identity for some while it is exploited politically as a means of opposition by others. Others again regard udal law as insignificant. There are differing and contested interpretations of history locally. Debates on the significance of udal law and related historical matters receive nevertheless good coverage in the local press. The references in SOUL's publications and the Udal Law website to legal cases involving indigenous rights in other parts of the world serve to provide new arguments and publicity for what must nonetheless be regarded as a fringe group. The globalization of the indigenous discourse has been strongly facilitated by information put out on the Internet, but this information and the uses that it is put to need to be scrutinized with a highly critical eye.

Open Access This article is distributed under the terms of the Creative Commons Attribution Noncommercial License which permits any noncommercial use, distribution, and reproduction in any medium, provided the original author(s) and source are credited.

\section{References}

Bäcklund, J. (2001). War or peace? The relations between the Picts and the Norse in Orkney. Northern Studies, 36, 33-47.

Balfour, D. (1859). Oppressions of the sixteenth century in the islands of Orkney and Shetland from original documents. Edinburgh: Maitland Club.

\footnotetext{
$\overline{7}$ Information by e-mail from a member of the Orkney Movement, October 2007.
}

Bennett, R. J. (1985). Regionalist movements in Britain: A review of aims and status. Environment and Planning $C$ : Government and Policy, 3(1), 75-96.

Brown, C. G. (1998). Up-Helly-Aa: Custom, culture and community in Shetland. Manchester: Mandolin.

Crawford, B. (1969). The pawning of Orkney and Shetland: A reconstruction of the events of 1460-1469. Scottish Historical Review, 48(1), 35-53.

Dickinson, W. C. (1954). Odal rights and feudal wrongs. In W. D. Simpson (Ed.), The Viking Congress, Lerwick, July 1950 (pp. 142-160). Edinburgh \& London: Oliver and Boyd.

Dobie, W. J. (1936). Udal law. In The Stair Society: An introductory survey of the sources and literature of Scots law (pp. 445-460). Edinburgh.

Drever, W. P (1933). Udal law. In Encyclopaedia of the laws of Scotland, XV (pp. 321-336). Edinburgh: W. Green \& Son Ltd.

Falk, R., Elver, H., \& Hajjar, L. (Eds.). (2008). Human rights: Critical concepts in political science, $V$. London \& New York: Routledge.

Fenton, A. (1978). The Northern Isles: Orkney and Shetland. Edinburgh: John Donald.

General Registry Office of Scotland. (2001). 2001 Population report. Table 2 census day population counts by age, sex, and council area; 29 April 2001. http://www.gro-scotland. gov.uk/statistics/publications-and-data/population-estima tes/poprep/poprep11.html. Accessed October 20, 2007.

International Labour Organization. (2006 [1957]). C 107 Indigenous and Tribal Populations Convention, 1957: Convention Concerning the Protection and Integration of Indigenous and Other Tribal and Semi-Tribal Populations in Independent Countries. ILOLEX database of international labour standards. http://www.ilo.org/ilolex/cgi-lex/con vde.pl?C107. Accessed August 5, 2009.

International Labour Organization. (2006 [1989]). C 169 Indigenous and Tribal Populations Convention, 1989: Convention Concerning Indigenous and Tribal Peoples in Independent Countries. ILOLEX Database of International Labour Standards. http://www.ilo.org/ilolex/cgi-lex/con vde.pl?C169. Accessed August 5, 2009.

Jakobsen, J. 1985 [1928]. An etymological dictionary of the Norn language in Shetland. Lerwick: Shetland Folk Society.

Jones, M. (1996a). Perceptions of udal law in Orkney and Shetland. In D. J. Waugh (Ed.), Shetland's northern links: Language and history (pp. 186-204). Edinburgh: Scottish Society for Northern Studies.

Jones, M. (1996 [2001]). Scots and Norse in the landscape of Orkney and Shetland: visible landscape and mental landscape. In F. H. A. Aalen \& M. Hennessy (Eds.), Proceedings of The Permanent European Conference for the Study of the Rural Landscape: Papers from the 17th Session, Trinity College Dublin, 1996 (pp. 4-10). Dublin: Department of Geography, Trinity College, University of Dublin.

Jones, M. (2005). Law and landscape-some historical-geographical studies from Northern Europe. In T. Peil \& M. Jones (Eds.), Landscape, law and justice: Proceedings of a conference organised by the Centre for Advanced Study at the Norwegian Academy of Science and Letters, Oslo 
15-19 June 2003 (pp. 95-109). Oslo: Novus forlag-Instituttet for sammenlignende kulturforskning.

Lâm, M.C. (2008 [2004]). Remembering the country of their birth: indigenous peoples and territoriality. In R. Falk, H. Elver \& L. Hajjar (Eds.), Human rights: Critical concepts in political science, II (pp. 424-447). London \& New York: Routledge.

Mackenzie, J. (1836 [1750]). The general grievances and oppression of the Isles of Orkney and Shetland. Edinburgh: Laing and Forbes.

Office of Public Sector Information. (2000). Abolition of Feudal Tenure etc. (Scotland) Act. http://www.opsi.gov. uk/legislation/scotland/acts2000/asp_20000005_en_1. Accessed October 20, 2007.

Øien, T. (2005). The Northern Isles-between two nations. Northern Studies, 39, 80-104.

Ryder, J. (1989). Udal law. In W. D. H. Sellar (Ed.), The laws of Scotland: Stair memorial encyclopaedia, 24 (pp. 193-219). Edinburgh: The Law Society of ScotlandButterworths.

Sellar, W. D. H. (1987). Custom as a source of law. In T. Smith (Ed.), The laws of Scotland: Stair memorial encyclopaedia, 22 (pp. 176-198). Edinburgh: The Law Society of Scotland-Butterworths.

Smith, B. (2001). The Picts and the martyrs or did Vikings kill the native population of Orkney and Shetland? Northern Studies, 36, 7-32.

Smith, D. (1978). Udal law. In Lord Kilbrandon (Ed.), The Shetland report: A constitutional study (pp. 197-203). Edinburgh: Nevis Institute.

Smith, T. B. (1973). The law relating to the treasure. In A. Small, C. Thomas, \& D. M. Wilson (Eds.), St. Ninian's Isle and its treasure, I (pp. 149-166). Oxford: Oxford University Press.

Smith, T. B. (1989). Udal law. Editorial excursus by the late Sir Thomas Smith. In W. D. H. Sellar (Ed.). The laws of Scotland: Stair memorial encyclopaedia, 24 (pp. 219-230). Edinburgh: The Law Society of ScotlandButterworths.

SOUL. (2004). The SOUL Report: Analysis of the findings of the association to autumn 2004. Cunningsburgh: Shetland and Orkney Udal Law Association.

S.O.U.L. (n.d.). Shetland \& Orkney Udal Law group: Wake up Shetland! S.O.U.L. udal law documentation. http://www. udallaw.com/documentation.htm. Accessed May 31, 2007.

Thomson, W. P. L. (1985). The Udal League. The Orkney View, 2, 15-17.

Thomson, W. P. L. (2001 [1987]). The new history of Orkney. Edinburgh: Mercat Press.

Townsend, J. A. B. (1992). The Viking Society: A centenary history. Saga-Book, 23(4), 180-212.

United Nations. (1987). Study of the problem of discrimination against indigenous populations, V. E/CN.4/Sub. 2/1986/7 Add. 4. New York: United Nations.

United Nations. (1996). Working paper by the ChairpersonRapporteur, Mrs. Erica-Irene A. Daes, on the concept of 'indigenous people'. E/CN.4/Sub.2/AC.4/1996/2. United Nations, Economic and Social Council, Commission on Human Rights. http://www.unhchr.ch/Huridocda/Hurido ca.nsf/(Symbol)/E.CN.4.Sub.2.AC.4.1996.2.En?Open document. Accessed August 3, 2009.

United Nations. (2004). The concept of indigenous peoples: Background paper prepared by the Secretariat of the Permanent Forum on Indigenous Issues. PFII/2004/WS.1/ 3. United Nations, Department of Social and Economic Affairs. http://www.un.org/esa/socdev/unpfii/documents/ workshop_data_background.doc. Accessed May 12, 2008.

United Nations. (2007). United Nations Declaration on the Rights of Indigenous Peoples Adopted by General Assembly Resolution 61/295 on 13 September 2007. http://www.un.org/esa/socdev/unpfii/en/drip.html. Accessed October 20, 2007.

Wikipedia. (2005). Category: Indigenous peoples of Europe. http://en.wikipedia.org/wiki/Category:Indigenous_peoples_ of_Europe. Accessed May 31, 2007.

Wikipedia. (2007). Indigneous peoples. http://en.wikipedia. org/wiki/Indigenous_peoples. Accessed May 30, 2007.

World Bank. (1991). The World Bank operational manual: Operational Directive OD 4.20 September 1991: Indigenous peoples. http://hei.unige.ch/ clapham/hrdoc/docs/ WBOD4.20.htm. Accessed May 31, 2007.

World Bank. (2005). The World Bank operational manual: Operational Policies OP 4.10 January 2005: Indigenous peoples. http://wbln0018.worldbank.org/Institutional/Man uals/OpManual.nsf/B52929624EB2A3538525672E00775 F66/0F7D6F3F04DD70398525672C007D08ED?Open Document. Accessed May 12, 2008.

Zetland County Council Act 1974. (1974). (London: Her Majesty's Stationery Office). http://www.opsi.gov.uk/acts/loc alact1974/pdf/ukla_19740008_en.pdf. Accessed August 5, 2009.

\section{Legal cases}

Scotland

Bruce v. Smith 189017 R 1000.

Smith v. Lerwick Harbour Trustees 19035 F 680.

Lord Advocate v. Balfour 1907 SC 1360.

Lord Advocate v. University of Aberdeen and Budge 1963 SC 533.

Shetland Salmon Farmers Association v. Crown Estate Commissioners 1990 SCLR 483.

Australia

Mabo and others v. Queensland (No. 2) [1992] HCA 23; (1992) 175 CLR 1 F.C. 92/014 (3 June 1992).

Canada

Delgamuukw v. British Columbia [1997] 3 S.C.R. 1010. 